\title{
Systemic Immunological Responses Among Dental Infection Patients
}

\author{
Zainab Khudher Ahmad Al Mahdi*, Fatima Malik Abood \\ Department of Microbiology, College of Dentistry, University of Babylon, Hilla City, Iraq \\ Email address: \\ dent.zainab.almahdi@uobabylon.edu.iq (Z. K. A. Al Mahdi) \\ ${ }^{*}$ Corresponding author
}

\section{To cite this article:}

Zainab Khudher Ahmad Al Mahdi, Fatima Malik Abood. Systemic Immunological Responses Among Dental Infection Patients. International Journal of Immunology. Vol. 9, No. 1, 2021, pp. 6-12. doi: 10.11648/j.iji.20210901.12

Received: December 5, 2020; Accepted: January 12, 2021; Published: January 22, 2021

\begin{abstract}
Dental infections are common health problems, evaluating of some systemic immunological responses are the aim of our study. Our study considered isolation of dental infection bacteria and quantitative evaluation of serum. IgA, IL-4, IL-7 and CD4 and CD8 molecules among dental plaque patients and control group. Oral bacteria from dental infection patients were isolated in appropriate media and diagnosed by biochemical tests and in vitro quantitative determination of serum IgA, IL-4, IL-7 and CD4 and CD8 molecules using ELISA technique. Single and mixed bacterial isolates were noted, mixed infection were (59.25\%), the nature of bacteria was Gram positive cocci Streptococcus viridans, Streptococcus pyogenes and Staphylococcus aureus, and Lactocacilli spps, in addition to Gram negative rods black- pigmented bacteria, Klebsilla pneumonia, and Esherishia coli. Serum IgA was higher in patients $(368.8 \pm 182.5) \mathrm{ng} \backslash \mathrm{ml}$ than in control group (319.92 \pm 79.26$) \mathrm{ng} \backslash \mathrm{ml}$. Serum IL-4 was higher patients (285.33 \pm 86.12$) \mathrm{pg} / \mathrm{ml}$ than in control group (257.7 \pm 94.14$) \mathrm{pg} \backslash \mathrm{ml}$. Serum IL-7 was higher in control group (19.59 \pm 4.14$)$ $\mathrm{pg} / \mathrm{ml}$ than in dental plaque patients $(17.98 \pm 3.18) \mathrm{pg} / \mathrm{ml}$. Serum CD4 molecules was higher in control group (1.371 \pm 0.5242$)$ $\mathrm{ng} / \mathrm{ml}$ than in dental plaque patients $(1.326 \pm 0.1292) \mathrm{ng} / \mathrm{ml}$. Serum CD8 molecules shows non-significant elevation in patients group $0.5825 \pm 0.02717(\mathrm{ng} \backslash \mathrm{ml})$ than in control group $0.51 \pm 0.01643(\mathrm{ng} \backslash \mathrm{ml}) \mathrm{P} \leq 0.05$. Mean of the CD4/CD8 ratio was higher $2.783 \pm 1.126$ in control group while it was $2.355 \pm 0.24$ in dental plaque patients, however the differences were non-significant $(\mathrm{P} \leq 0.05)$. The present study conclude that the bacteria isolated from dental infection patients were mixed more than single infection, there were non-significant elevation in IgA, IL-4, and CD8 in patients while IL-7 and CD4 was lower in patients group than in control group, while CD4\CD8 ratio were lower in patients group, these result reflect the fact that mucosal antigen induce systemic tolerance to some extent since these bacteria present in oral cavity in early childhood. Therefor removing these bacteria always the best way to prevent such infections.
\end{abstract}

Keywords: Dental Infection, Immune Response, Cytokine, Oral Bacteria

\section{Introduction}

Dental caries have familiarly been considered the most important worldwide oral health problems [1]. The disease is multifactorial, affected by host and environmental factors that occurs due to homeostasis imbalance between the host and microbiota, host immune defense mechanisms may effect in the bacterial colonization and some host disorders can affect these mechanisims such as general immune deficiencies associated with malnutrition, inherited or medication disorders [2].

Bacteria is important agent in dental infection, the nature of such infection is polymicrobial, mixed aerobic and an aerobic bacteria encompassed Gram positive and Gram negative bacteria [3].

Streptococcus viridans are abundant among oral bacteria and one member of the cluster is $S$. mutans, the reason behind tooth decay in most cases. likewise $S$. sanguinis is additional potential reason, when introduced into the blood, they have the potential of initiating endocarditis, specifically in whom with injured heart valves. They are the most common reason of sub-acute bacterial endocarditis [4]. 
Microbial biofilm composed of Staphylococcus aureus and Streptococcus mutans responsible for formation pathogenic biofilm, chronic infection and dental caries [5].

Lactobacilli unlike most indigenous microbes. Some species lactobacilli are commensal, behave as planktonic, opportunistic colonizers that may gather and multiply solitary in certain restrictive niches of the host, at least within the oral cavity. There is relation between the number of lactobacillus and dental caries, lactobacilli are not existing in adults without caries lesions or that they present lower than the detection level, the ability of lactobacilli and mutans streptococci to ferment a variety of carbohydrates and to persist in a low $\mathrm{pH}$ environment is the main hallmark of the dental caries paradigm $[3,6]$.

Streptococcus pyogenes infect the mucosal surface and can isolated from oral cavity, the bacteria capable to adhere the mucosal surface and bind salivary pellicle on the surface of tooth [7] and responsible for many odontogenic infection [8].

Regarding to anaerobic Gram negative bacteria, black pigmented bacteria, isolated from dental abscess are represent expected members of the oral microbiota and become highly damaging agent influenced by capacity to participate in oral biofilm formation [9] Additionally, the virulence factors of dark pigmented bacteria has ability to fight phagocytosis, destroy immunoglobulins and increase pathogenesis when mutual with other bacterial strain [10]. Furthermore, gram-negative aerobes $(K$. pneumoniae and $E$. coli) present in dental abscesses as gram's negative bacilli from oral lesions at normal frequency, also they stated K. pneumoniae and E. coli as oral normal flora that settled oral cavity and initiated odontogenic abscess [11].

Evaluation aspect of systemic immune response represented by serum IgA level and anti-inflammatory IL-4 cytokine as regulatory cytokine for humoral and adaptive immune responses [12, 13] reflect the adaptive immune responses among patients suffer from dental bacterial infection, as well as IL-7 which is important cytokine in both $\mathrm{T}$ and $\mathrm{B}$ cell development $[14,15]$ these combined with estimation of cell mediated immunity by measurement of both CD4 and CD8 molecules [16, 17].

\section{Main Body}

\subsection{Patients and Sample Collection}

This study involved the analysis of 20 patients with mean of age 57.3 range from 45 to 72 year with dental infection and 5 control group with mean of age 52.2 during 2017. Samples were collected after patients agreement by dentist specialized in microbiology.

For bacteriological examination, pus samples taken by the swabs or paper point size $40 \mathrm{~mm}$ were inserted in root canal and gingival pockets for $60 \mathrm{~s}$ and the samples were immediately placed into thyioglycolate broth for anaerobic culture and BHIB for aerobic culture then transport samples to the laboratory of oral microbiology for isolation and discovery of studied bacteria. One of the culture plates was incubated at $37^{\circ} \mathrm{C}$ in the incubator under aerobic and an aerobic environment was incubated in an anaerobic jar or $\mathrm{Co} 2$ incubator The bacteriological study including cultural properties, microscopic examination and biochemical tests was done according to MacFaddin, 2000; Forbes et al., 2007 and Al-Rawi, 2012 [18-20].

\subsection{Blood Collection and Storage}

Blood were collected by sterile one-use syringes, from each group, blood samples were centrifuged for 15 minutes at $1000 \times \mathrm{g}$, the supernatant were collected and saved at $-20^{\circ} \mathrm{C}$, the assay was carried out during the first month after storage.

\subsection{In Vitro Quantitative of Antibody and Cytokines}

In vitro quantitative determination of IgA, IL-4 and IL-7 in serum of patients group and control. group using Sandwich-ELISA as in manufacture instructions (Elabscience Biotechnology Co., Ltd).

\subsection{Serological Markers of Cell-mediated Immunity}

Serum soluble CD4 and CD8 were rummage-sale as markers for cell mediated immunity among odontogenic patients (Elabscience company).

\subsection{Statistical Analysis}

Statistical analysis comprise unpaired t-test for determine the significant of the differences between the two mean groups and graphs were done using GraphPad Prism-7 software CA. USA.

\section{Results}

\subsection{Bacterial Isolates}

Most bacteria insulated from dental plaque were gram positive bacteria. (88.88\%) while gram negative bacteria $(11.11 \%)$. Present data displays that the nature of bacterial infection mostly were mixed infection (Total $=32$ isolates) while single bacterial infection were (total $=22$ isolates). The percentage of infection with S. viridians was higher than other bacteria followed by $\mathrm{S}$. pyogenes both in single and mixed infection. cases. Black pigmented colony was noted among. single isolates infection (13\%) and not recorded with other bacteria (Table 1, Figure 1).

\subsection{Antibody Response}

Result shows that serum IgA was higher among dental plaque patients than in control group (mean $\pm \mathrm{SEM}=368.9 \pm 38.92$ (ng. $\backslash \mathrm{ml})$ and $319.9 \pm 35.45(\mathrm{ng} \backslash \mathrm{ml})$ respectively), however these differences was non significant $(\mathrm{t}=0.5802,(\mathrm{P} \leq 0.05))$, (table 2; figure 2-A).

\subsection{Cytokine Profile}

IL-4 was higher in test group than in control group 
(mean=285.3 $\pm 27.23(\mathrm{pg} \backslash \mathrm{ml})$ and $257.7 \pm 54.36$ respectively), the differences were non significant $(\mathrm{t}=0.479, \mathrm{df}=11, \mathrm{P}=0.6$; Table 2, figure 2-B.

IL-7 was higher in control group than in test group $(19.59 \pm 1.855 .(\mathrm{pg} \backslash \mathrm{ml})$ and $17.99 \pm 0.6795(\mathrm{pg} \backslash \mathrm{ml})$ respectively and the differences were non significant $(\mathrm{t}=0.96, \mathrm{P}=0.37$; table 2, figure 2-C) $(\mathrm{P} \leq 0.05)$.

\subsection{Serum CD4 \& CD8}

The mean of serum CD4 molecules was $1.371 \pm 0.52(n=4)$ (ng $\backslash \mathrm{ml})$ in control group while it was $1.326 \pm 0.1292$. $(\mathrm{n}=20)$ (ng $\backslash \mathrm{ml}$ ) in dental plaque patients while serum soluble CD8 was $0.51 \pm 0.01643$. (ng $\backslash \mathrm{ml})(\mathrm{n}=20)$ in control group and $0.5825 \pm 0.02717(\mathrm{ng} \backslash \mathrm{ml}) \mathrm{n}=22$ in dental plaque patients, (Table 2, figure 2-D\&E).

Table 1. Type of bacterial isolates and the percentage of isolated as mixed and single isolates.

\begin{tabular}{llll}
\hline \multirow{2}{*}{ Bacterial Isolates } & \multicolumn{1}{c}{ Type of isolates } & No. \& \% \\
\cline { 2 - 4 } & Single & Mixed & $16(29.5 \%)$ \\
\hline S. viridians & 6 & 10 & $12(22.22 \%)$ \\
S.pyogenes & 5 & 7 & $11(20 \%)$ \\
S.aureus & 5 & 6 & $9(16.6 \%)$ \\
Lactobacilli spp & 2 & 7 & $3(5.3 \%)$ \\
Black-pigmented bacteria & 3 & 0 & $2(3.4 \%)$ \\
K. pneumonia & 1 & 1 & $1(1.3 \%)$ \\
E. coli & 0 & 1 & $54(100 \%)$ \\
Total & 22 & 32 & \\
\hline
\end{tabular}

Mean of the CD4/CD8 ratio was 2.68 in control group while it was 2.27 in dental plaque patients all results shows non-significant differences $(\mathrm{P} \leq 0.05)$.

Table 2. Immune response (antibody; cytokines \& cell mediated Immunity) of dental dental patients among test and control groups.

\begin{tabular}{lll}
\hline Immune response parameter & Test group (mean \pm St.d) & Control group (mean \pm St.d) \\
\hline IgA & $368.9 \pm 38.92(\mathrm{ng} \backslash \mathrm{ml})$ & $319.9 \pm 35.45(\mathrm{ng} \backslash \mathrm{ml})$ \\
IL-4 & $285.3 \pm 27.23(\mathrm{pg} / \mathrm{ml})$ & $257.7 \pm 54.36(\mathrm{pg} / \mathrm{ml})$ \\
IL-7 & $17.99 \pm 0.6795(\mathrm{pg} / \mathrm{ml})$ & $19.59 \pm 1.855(\mathrm{pg} / \mathrm{ml})$ \\
CD4 & $1.326 \pm 0.1292(\mathrm{ng} \backslash \mathrm{ml})$ & $1.371 \pm 0.52(\mathrm{ng} \backslash \mathrm{ml})$ \\
CD8 & $0.5825 \pm 0.02717(\mathrm{ng} \backslash \mathrm{ml})$ & $0.51 \pm 0.01643(\mathrm{ng} \backslash \mathrm{ml})$ \\
\hline
\end{tabular}

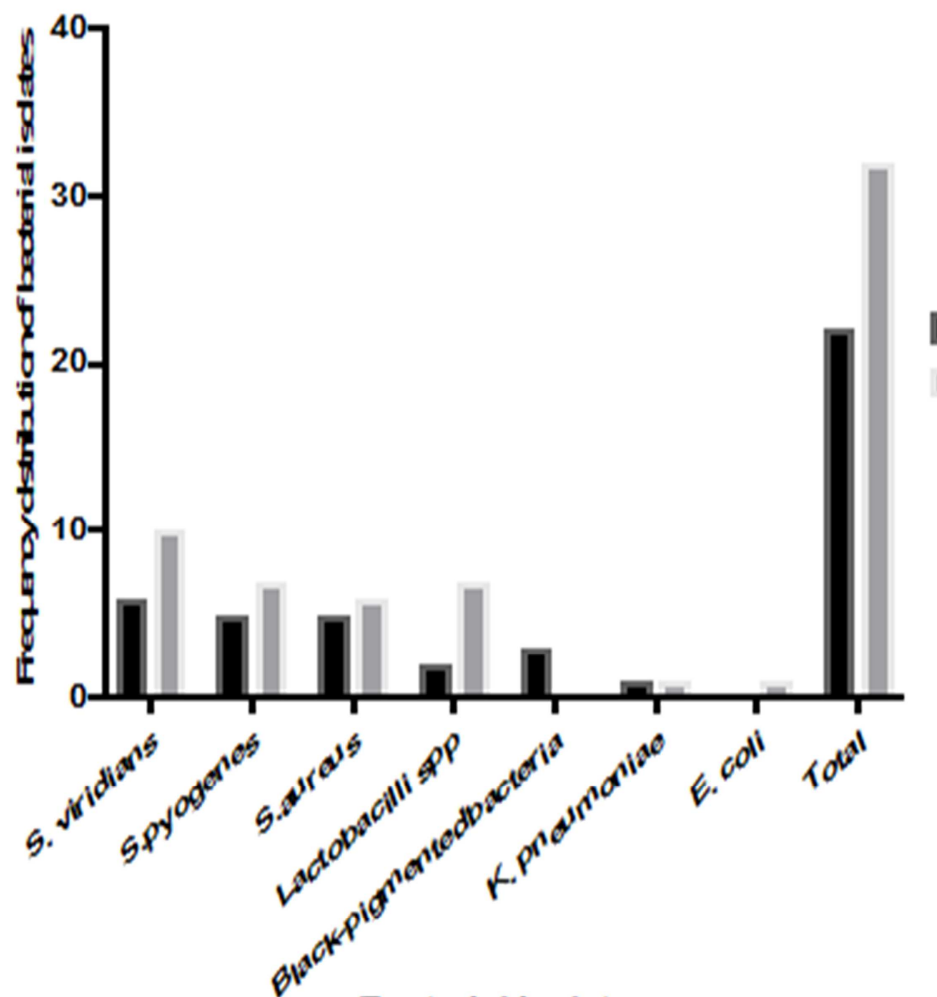

Single infection

Mixed infection

Bacterial isolates

Figure 1. The nature of bacterial infection among dental infection patients (Mixed and single infection). 


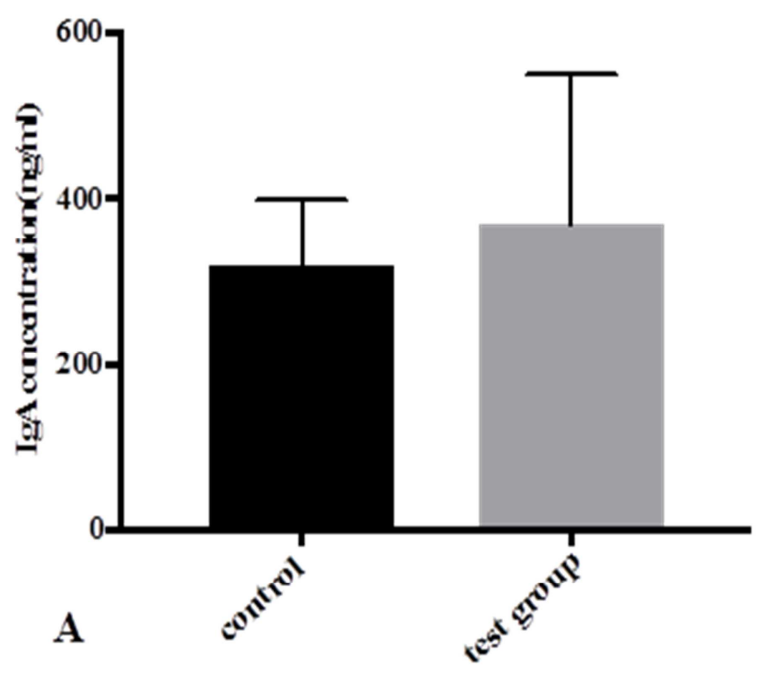

Groups of study

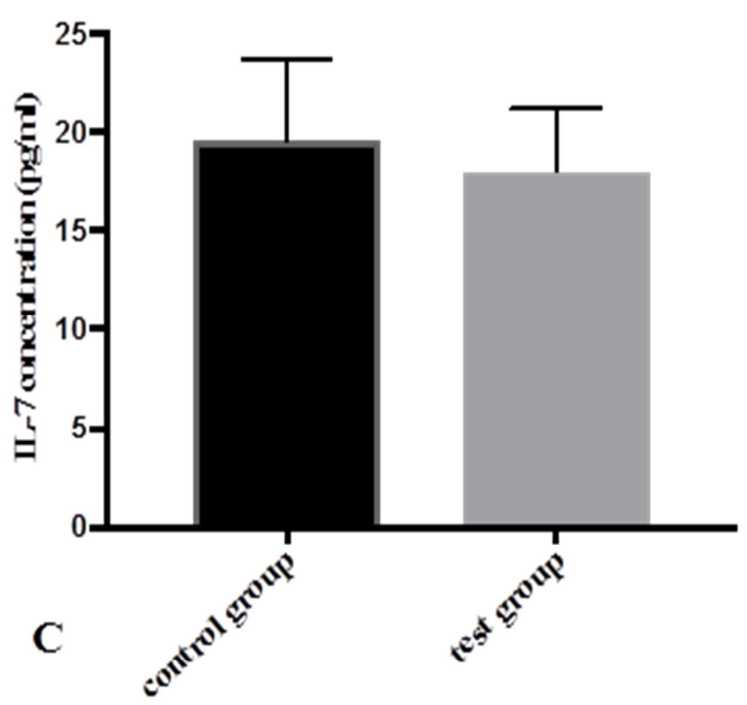

Groups of study

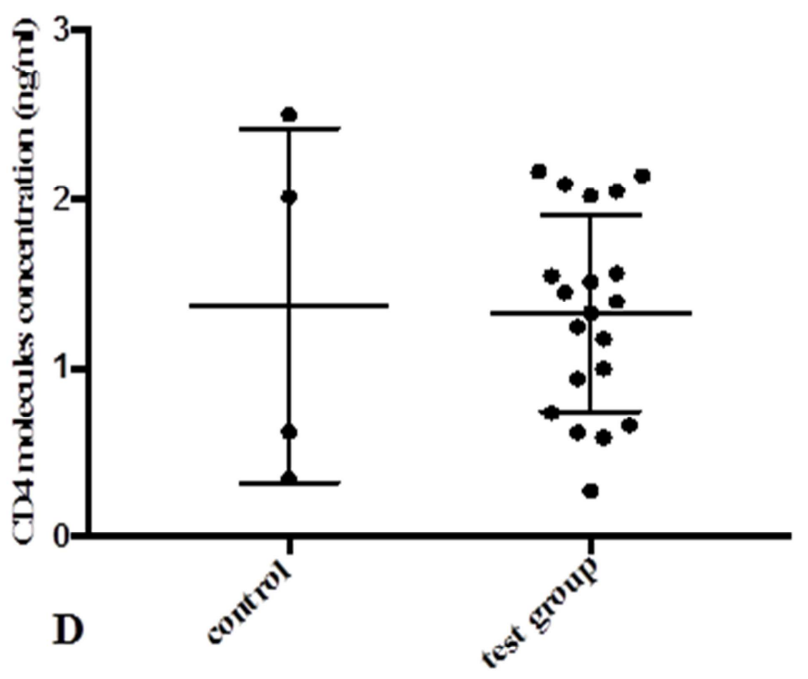

Groups of study
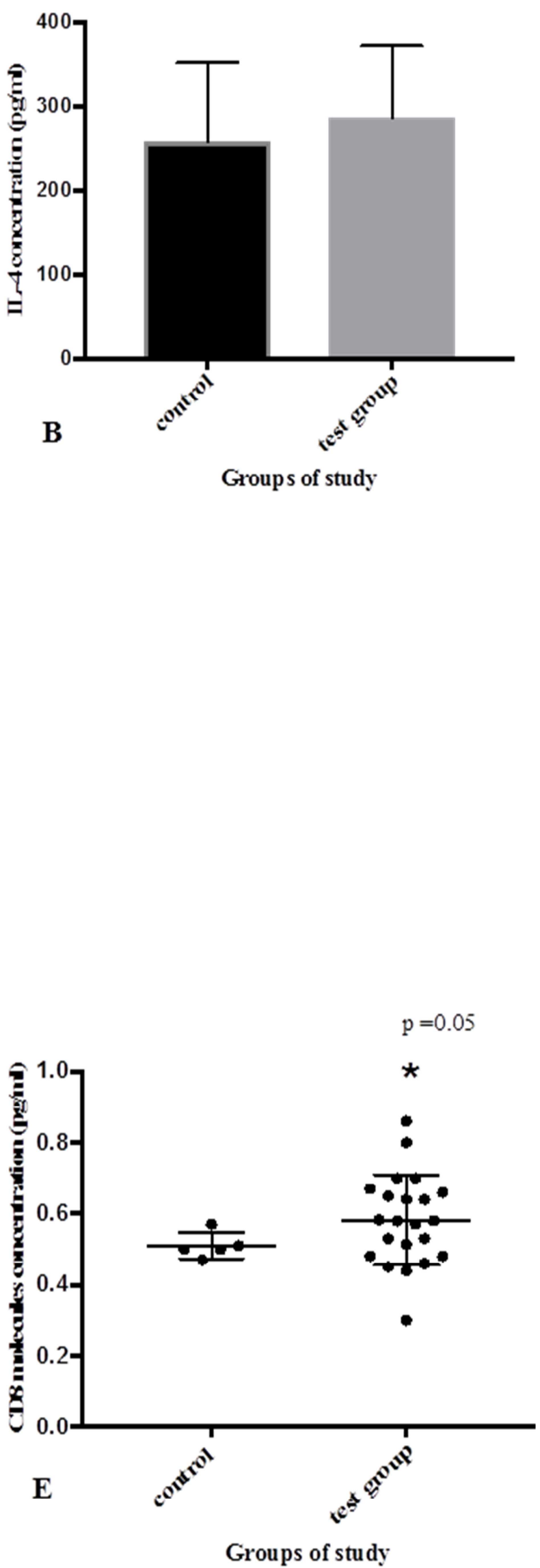

Groups of study

Figure 2. Immune response parameters among dental infection patients (test group) and control group; A: IgA concentration; B: IL-4 concentration; C: IL-7 concentration (Bar graphs represent mean of cytokine concentration $\pm S D V$ ); D: CD4 concentration and E: CD8 concentration. 


\section{Discussion}

The current data were detecting the possible bacteria among dental infection cases acquired from dental plaque of different pockets depths. Results shows that most infections are usually polymicrobial in nature $(59.25 \%)$, these result was in agree with other studies [21].

Gram positive bacteria were dominant in our study (88\%), the consequences revealed that 16 (29.5) of isolate revealed positive bacterial culture of $S$. viridians (Table $1 \&$ Figure 1) whereas 13 (24), 11 (20) isolates of Streptococcus. pyogenes and Staphylococcus aureus respectively with medium percentage of isolates belong to Lactobacillus spp. 9 (16.5) and low gram negative percentage of isolates belong to black pigmented bacteria, Klebsiella pneumoniae and Escherichia coli $3(5.3 \%), 2$ (3.4\%), 1 (1.3\%) respectively.

Our results recorded the highest percentage was Streptococcus viridians, these bacteria are most abundant in the oral cavity species, one is the most important is $S$. mutans the aciduric species, excessive acidification of the oral environment by these bacteria is directly associated with the development of dental caries [22].

$S$. mutanse on teeth by PCR technique and proved present in higher percentage among other streptococci [23].

Viridance group streptococci found normally in oral cavity, any breach in oral mucosal barrier resulting the penetration of microorganisms into the bloodstream, causing bacteremia and bacterial endocardiatis [24].

Lactobacillus spp. common oral inhabitants, but include less than $1 \%$ of the oral flora. Dental plaque biofilms, commonly in small numbers; advancing forward-facing of dental caries. As levels of salivary lactobacilli associate well with consumption of dietary carbohydrates, they are used to distinguish the cariogenic potential of the diet [6].

Gram positive aerobic/facultative anaerobic $S$. aureus detected in 11 case $(20 \%)$ as single and mixed infection. $S$. aureus are associated with human infections, such as facial furuncle and carbuncle, loose connective tissue inflammation, and tumor post-operative wound infections [25]. Bacterial oral biofilm serve as a reservoir of infection for respiratory bacteria, Staphylococcus aureus, and enteric bacteria that has been shown to colonize the teeth of patients self-proclaimed to hospitals or long-term care facilities. These bacteria when released into saliva may then aspirated into the lower airway creating respiratory infection. Intubation is another way by which oral bacteria can be introduced into the respiratory system. Inflammatory cytokines delivered by the periodontium may possibly be mechanism through which respiratory disease are associated with oral health. These mediators present in tissues of inflamed gingiva, enter the gingival crevicular fluid and then the saliva. These mediators can have proinflammatory outcomes in the lower airway [26].

Current study shows Gram negative anaerobic black pigmented bacteria $(5.3 \%)$ as single infection. Black pigmented an anaerobes include $P$. gingivalis and $P$. intermedia found in dental plaque in $0.1 \%$ and increase quantitatively in the course of infections such as progress of gingival lesion.

$P$. gingivalis have virulence factors such as fimbriae, capsule and production of enzymes such as collagenase and trypsin-like protease. $P$. gingivalis constrains neutrophil migration into the lesion [27].

Plaque biofilm contain a lot of biologically active products from gram-positive and gram-negative bacteria colonize the tooth surface around the gingival margin and interproximal areas. These products include endotoxins and other bacterial toxins [28-30]. These products and the host immunological responses products such as cytokines infiltrate the gingival epithelium and initiate a host response that lead to gingivitis. Symptoms of gingivitis can be notified clinically with changes in tissue color from pink to red, swelling and bleeding upon probing [31]. Chronic gingivitis that remains for years may bring the basis for more concern for systemic health than a periodontitis situation that is more readily treated. As the plaque biofilm continues to increase, soluble compounds penetrate the secular epithelium. This, in turn, induce the gingival epithelium to produce mediators including prostaglandins, cytokines as interleukin-1 beta (IL-1), tumor necrosis factor alpha and enzymes such as matrix metalloproteinases. These products influence chemotaxis recruit neutrophils to the region and lead to increased permeability of gingival vessels that induce plasma proteins to migrate from the blood vessels into the tissue. As the inflammatory process progresses, more mediators are produced, and more cell types are employed to the area including neutrophils, monocytes and T-cells. Chronic inflammation results in production more proinflammatory cytokines signaling of fibroblasts in the tissues [32].

Present data shows elevation in serum concentrations of IgA in patients, IgA in serum is linked positively with age, sex, alcohol heavy drinking, obesity and metabolic syndrome [33].

Serum IgA have a pro-inflammatory immune responses, by induction pro-inflammatory cytokines production such as TNF, IL-1 $\beta$, and IL-6 and enhance phagocytosis. In the liver IgA does not only mediate bacterial clearance, but that $\operatorname{IgA}$ also contributes to initiation of protective immunity by controlling the balance between immune tolerance and inflammation by Kupffer cells. Monomeric or dimeric IgA also have Inhibitory signaling, acting an active role in homeostasis by suppression of inflammatory functions [34].

Our result recorded elevation in IL-4 among test group, however the differences were non-significant, the anti-inflammatory action of IL-4 is well documented both in vitro and in vivo. IL-4 attenuates the activation of various immunocompetent cells, including neutrophils, monocytes, and macrophages, by limiting the production of proinflammatory cytokines and regulate the inflammation processes [35].

Elevation level of anti-inflammatory IL-4 cytokine in patients may reproduce the immune tolerance which may be encouraged by oral administration of antigen, previous work on rabbits displays that giving antigen in oral rout record 
significant lower in antibody production, proinflamatory IL- $1 \alpha$ in associate with rabbits those administrated to the antigen by intramuscular rout [36].

The elevation in anti-inflamatory cytokine IL-4 in dental infection patients combined with lowering in IL-7 concentration with in the same group comparing with control group (Table 2, figure 2-B).

IL-7 motivates the differentiation of multipotent (pluripotent) hematopoietic stem cells into lymphoid progenitor cells, it furthermore stimulates propagation of all cells in the lymphoid lineage (B cells, T cells and NK cells). It is significant for proliferation through certain steps of B-cell maturation, T and NK cell survival. Il-7 provides an important signal for survival of thymocyte and pre-B cell, when IL-7 withdrawn theses cell rapidly die by apoptosis [19].

Serum CD4 molecules was higher in control group $(2.0226$ $\pm 1.71) \mathrm{ng} / \mathrm{ml}$ than in dental plaque patients $(1.84 \pm 2.38) \mathrm{ng} / \mathrm{ml}$ and serum CD8 molcules was higher $(0.58 \pm 0.12)$ in $\mathrm{ng} / \mathrm{ml}$ dental plaque patients than in control group $(0.03 \pm 0.12) \mathrm{ng} / \mathrm{ml}$ Mean of the CD4/CD8 ratio was 3.96 in control group while it was 2.27 in dental plaque patients.

\section{Conclusions}

Our work conclude that the nature of bacteria isolated from dental infection patients were mixed more than single infection. There were differences in IgA, IL-4, IL-7 however the differences were non-significant, there were non-significant differences in soluble CD4 \& CD8 between dental plaque patients and in control group also dental plaque cause changing in $\mathrm{CD} 4 / \mathrm{CD} 8$ ratio. The non-significant differences between patients and control group may be due to that the antigens in oral cavity or mucosal surface induce a degree of systemic immune tolerance since these bacteria present in early childhood and there were boundaries between the presence of bacteria and the immune responses against such invader, therefor removing the bacteria is important in prevention such infections.

\section{Acknowledgements}

The authors would like to acknowledge college of dentistry/ University of Babylon for providing services and support to appearance this study. Also, we would thank Dr. Alaa Tariq at college of science/ Babylon University for doing ELISA test.

\section{References}

[1] WHO, World Health Organization. 2019. Oral health. What is the burden of oral disease?. WHO. int.

[2] Negrini T. D,; Duque C.; Hofling J. F. and Goncalves R. B. (2009). Fundamental mechanisms of immune response to oral bacteria and the main perspectives of a vaccine against dental caries: A brief review. Rev. odonto ciênc. 24 (2): 198-204.

[3] Samaranayke L. (2012). Essential microbiology for dentistry. 4th ed. Elsevier Ltd. P: 279-285.
[4] Baucells, B. J.; Mercadal Hally, M.; Álvarez Sánchez, A. T.; Figueras Aloy, J. (2016). Asociaciones de probióticos para la prevención de la enterocolitis necrosante y la reducción de la sepsis tardía y la mortalidad neonatal en recién nacidos pretérmino de menos de $1.500 \mathrm{~g}$ : una revisión sistemática". Anales de Pediatría. 85 (5): 247-255.

[5] Wang, H., \& Ren, D. (2017). Controlling Streptococcus mutans and Staphylococcus aureus biofilms with direct current and chlorhexidine. AMB Expr 7, 204.

[6] Caufield P W, Schon C N, Saraithong P and Argimon S. (2015). Oral Lactobacilli and Dental Caries, A Model for Niche Adaptation in Humans. J Dent Res 94 (9 Suppl): 110S$118 \mathrm{~S}$.

[7] Nobbs, A. H., Lamont, R. J., \& Jenkinson, H. F. (2009). Streptococcus adherence and colonization Microbiology and molecular biology reviews: MMBR, 73 (3), 407-450.

[8] Inagaki, Y., Abe, M., Inaki, R., Zong, L., Suenaga, H., Abe, T., \& Hoshi, K. (2017). A Case of systemic infection caused by Streptococcus pyogenes oral infection in an edentulous patient. Diseases (Basel, Switzerland). 5 (3), 17.

[9] Patel M, Chettiar TP, Wadee AA. (2009). Isolation of Staphylococcus aureus and black-pigmented bacteroides indicate a high risk for the development of Ludwig's angina. Oral Surg Oral Med Oral Pathol Oral Radiol Endod. 108 (5): 667-72.

[10] Sundqvist G. (1993). Pathogenicity and virulence of black-pigmented Gram-negative anaerobes. FEMS. Immunology and Medical Microbiology. 1 6: (2-3) 125-138.

[11] Hornick D., Allen, B. L. Horn and S. Clegg. (1992). Adherence to respiratory epithelia by recombinant Escherichia coli expressing Klebsiella pneumoniae type 3 fimberial gene products. Infect Immun. 60 (4): 1577-88.

[12] Bao K and Reinhardt R L. (2015). The differential expression of IL-4 and IL-13 and its impact on type- 2 immunity. Cytokine. 75 (1): 25-37.

[13] Luzina I G, Keegan A D, Heller N M, Rook G A W, Donohue T S and Atamas S P. (2012). Regulation of inflammation by interleukin-4: a review of "alternatives". Format: AbstractSend to J Leukoc Biol. 92 (4): 753-64.

[14] Lin J, Zhu Z, Xiao H, Wakefield M R, Ding V A, Bal Q and Fang Y. (2017). The role of IL-7 in immunity and cancer. Anticancer Res. 37 (3): 963-967.

[15] Roitt I. and Rabson A. (2000). Really Essential Medical Immunology. First published, Black well science. London. p: 72 .

[16] Frank L, Nugel E, Docke WD and Porstmann T. (1994). Quantitative determination of CD4/CD8 molecules by a cell marker ELISA. Clin Chem. 40 (1): 38-42.

[17] Diagbouga S, Durand G, Sanou PT, Dahourou H and Ledru E. (1999). Evaluation of a quantitative determination of CD4 and CD8 molecules as an alternative to CD4 and CD8 T lymphocyte counts in Africans. Tropical Medicine and International Health. 4 (2): 79-84.

[18] MacFaddin, J. F. (2000). Biochemical test for identification of medical bacteria. 3rd ed., Williams and Wilkins-Baltimor, USA. 
[19] Forbes, B. A.; Daniel, F. S.; and Akice, S. W. (2007). Bailey and Scott's diagnostic microbiology. 12th ed., Mosby Elsevier company, USA.

[20] Al-Rawi, A. M. (2012). Detection of Porphyromonas gingivalis from Periodontal Pocket Infection by Microbial Cultivation and PCR Techniques. J Rafidain Sci. 23: 39-55.

[21] Kityamuwesi R., Muwaz L, Kasangaki A, Kajumbula H, and Rwenyonyi C M. 2015. Characteristics of pyogenic odontogenic infection in patients attending Mulago Hospital, Uganda: a cross-sectional study. BMC Microbiol. 15: 46.

[22] Abranches J, Zeng L, Kajfasz JK, et al. (2018). Biology of Oral Streptococci. Microbiol. 6 (5): 10.1128/m.

[23] Al-Janabil A S, Al-Mahdi Z K and Alhamadi W W. (2019). Fixed Orthodontic Appliance Associated With Change in Bacterial Diversity During First Stage of Active Orthodonotic Treatment. J Global Pharma Technol. 11 (03): 439-448.

[24] Poveda-Roda R, Jiménez Y, Carbonell E, Gavaldá C, Margaix-Muñoz M, Sarrión Pérez G. (2008) Bacteremia originating in the oral cavity. A review. Med Oral Patol Oral Cir Bucal. 13 (6): E355-62.

[25] Zhou X, Li Y. (2015) Atlas of oral microbiology, from healthy microflora to disease. 1st Edition. Elsevier Inc. pp: 95.

[26] Scannapieco FA. (2004). Periodontal inflammation: from gingivitis to systemic disease? Compend Cont Educ Dent 2004; 25 (7) (Suppl 1): 16-25.

[27] Samaranayake L. (2012). Essential microbiology for dentistry. 4th ed. p 292. Elsevier Ltd, Inc, BV p: 292.

[28] Leishman S J, Do H L and Ford D J. 2010. Cardiovascular disease and the role of oral bacteria. J Oral Mcrobiol. 2: 5781: $1-13$.

[29] Mariotti A. (2004). A primer on inflammation. Compend Cont Educ Dent. 25 (7) (Suppl 1): 7-15.

[30] Armitage GC. (2003). Diagnosis of periodontal diseases. J Periodontol. 74; 1237-47.

[31] Scannapieco FA (2004). Periodontal inflammation: from gingivitis to systemic disease? Compend Cont Educ Dent. 25 (7) (Suppl 1): 16-25.

[32] Gurenlian J R. (2006). Inflamation: The relationship between oral health and systemic disease. Special supplemental issue. Sponsored by Colgate. P: 1-8.

[33] Gonzalez-Quintela, A, Alende R, Gude F, Campos J, Rey J, Meijide LM, Fernandez-Merino C and Vidal C. (2008). Serum levels of immunoglobulins (IgG, $\operatorname{IgA}, \operatorname{IgM}$ ) in a general adult population and their relationship with alcohol consumption, smoking and common metabolic abnormalities. Clin Exp Immunol. 151 (1): 42-50.

[34] Hansen IS, Baeten DLP, den Dunnen J. (2019). The inflammatory function of human IgA. Cell Mol Life Sci. 76: 1041-55.

[35] Park H-J, Shim HS, An K, Starkweather A, Kim KS and Shim I. (2015). IL-4 Inhibits IL- $1 \beta$-Induced Depressive-Like Behavior and Central Neurotransmitter Alterations. Mediators of Inflammation: 1-9.

[36] Shnawa, I M S, Al-Mahdi Z K A. (2015). Oral Mucosal Tolerance Versus Systemic Immune Response to Salmonella typhi Antigen. American J. Biome and Life Sci. Advances in Oral Immunity. 3 (4-1): 13-16. 